\title{
PENGARUH FASILITAS PERPUSTAKAAN, KINERJA PUSTAKAWAN DAN KUALITAS INFORMASI TERHADAP KEPUASAN MAHASISWA DALAM MENGGUNAKAN PERPUSTAKAAN POLITEKNIK NEGERI BATAM
}

\begin{abstract}
Adhitomo Wirawan ${ }^{1}$, Risfandi ${ }^{2)}$
1) Prodi Administrasi Bisnis Terapan Politeknik Negeri Batam,e mail:adhitomo@polibatam.ac.id 2) Prodi Administrasi Bisnis Terapan Politeknik Negeri Batam, email:sfandi633@gmail.com

\section{abstract}

This study aims to determine the influence of library facilities, librarian performance, and quality of information on user satisfaction (students). The respondents of this research are Batam State Polytechnic students. Data collection techniques used questionnaires and documentation. Test the research instrument by using the validity and reliability analysis. Data analysis method used in this research is descriptive analysis and multiple linear regression analysis. This analysis tool is used to know how far library facilities (X1), librarian performance (X2), information quality (X3), to student satisfaction (Y). Partial research results indicate that library facility variables, librarian performance and information quality have positive and significant influence
\end{abstract}

Keywords: library facilities, librarian performance, information quality, and user satisfaction.

\section{abstrak}

Penelitian ini bertujuan untuk mengetahui pengaruh fasilitas perpustakaan, kinerja pustakawan, dan kualitas informasi terhadap kepuasan pengguna (mahasiswa). Responden penelitian ini adalah mahasiswa Politeknik Negeri Batam. Teknik pengumpulan data menggunakan kuesioner dan dokumentasi. Uji instrument penelitian dengan menggunakan analisis validitas dan reliabilitas. Metode analisis data yang digunakan dalam penelitian ini adalah analisis deskriptif dan analisis regresi linier berganda. Alat analisis ini digunakan untuk mengetahui sejauh mana pengaruh fasilitas perpustakaan (X1), kinerja pustakawan (X2), kualitas informasi (X3), terhadap kepuasan mahasiswa (Y). hasil penelitian secara parsial menunjukkan bahwa variabel fasilitas perpustakaan, kinerja pustakawan dan kualitas informasi memiliki pengaruh positif dan signifikan

Kata Kunci: fasilitas perpustakaan, kinerja pustakawan, kualitas informasi, dan kepuasan pengguna. 


\section{PENDAHULUAN}

Perkembangan ilmu pengetahuan yang semakin pesat yang sangat berpengaruh besar tehadap kehidupan manusia yang semakin penuh tantangan di berbagai bidang ilmu. Untuk meningkatkan mutu dan kualitas suatu perpustakaan, perlu adanya sarana dan prasarana untuk menjadi salah satu indikator yang dijadikan sebagai parameter kinerja perpustakaan. Suatu perpustakaan sangat berpengaruh terhadap tersedianya fasilitas, jika kurangnya fasilitas akan berdampak pada keterbatasan layanan.

Politeknik Negeri Batam merupakan satusatunya Perguruan Tinggi Negeri Vokasi di kawasan perdagangan dan pelabuhan bebas Batam, Bintan, dan Karimun Provinsi Kepulauan Riau. Pada awalnya Polibatam merupakan perguruan tinggi swasta di bawah yayasan Pendidikan Batam yang beranggotakan Otorita Batam, Institut Teknologi Bandung, Pemerintah Kota Batam, dan Universitas Riau. Seiring dengan perkembangan kinerja dan prestasi yang diraih selama satu tahun dasawarsa, pada tanggal 18 Oktober 2010, pemerintah melalui Peraturan Mentri Pendidikan Nasional Nomor 26 Tahun 2010 menetapkan secara resmi Polibatam menjadi PTN dengan nama Politeknik Batam. Dengan demikian mulai tahun akademik 2011/2012, status mahasiswa dan lulusan Polibatam adalah mahasiswa dan lulusan perguruan tinggi negeri atau perguruan tinggi pemerintah.

Persaingan di bidang pendidikan tinggi yang mengharuskan Perguruan Tinggi Negeri (PTN) meningkatkan daya saingnya, baik dalam penyelenggaraan maupun dalam mutu lulusannya. Politeknik Negeri Batam dihadapkan pada persaingan yang semakin sengit, bukan hanya dengan Perguruan Tinggi Negeri (PTN) sejenis tetapi juga dengan Perguruan Tinggi Swasta (PTS) untuk menarik minat mahasiswa. Karena konsumen dari perguruan tinggi ini yaitu mahasiswa yang akan melanjutkan pendidikannya di perguruan tinggi tersebut. Saat ini banyak pertumbuhan perguruan tinggi swasta yang bermunculan dan memberikan program-program terbaru. Ini merupakan salah satu hal yang harus diperhatikan oleh Politeknik Negeri Batam agar para calon mahasiswa tetap memilih Politeknik Negeri Batam sebagai tempat untuk melanjutkan pendidikannya. Sedangkan pustakawan menurut PP No 24 tahun 2014 tentang pelaksanaan UU No 43 Tahun 2007 tentang perpustakaan bab 1 pasal 15 adalah seseorang yang memiliki kompetensi yang diperoleh melalui pendidikan dan pelatihan kepustakawanan serta tugas dan tanggung jawab untuk melaksanakan pengelolaan dan pelayanan perpustakaan.

Fungsi pustakawan ialah untuk melayani dan memberikan informasi kepada pengunjung, sehingga pengunjung mengetahui bagaimana pelayanan diperpustakaan, dan diharapakan pustakawanpun mampu untuk meramalkan apa yang diinginkan oleh pengunjung secara tidak langsung ialah unuk melayani pengunjung diperpustakaan bagaimana lengkap nya koleksi dan fasilitas diperpustkaan. Pustawakan bertanggung jawab dan memiki fungsi penting baik secara langsung maupun tidak langsung bagi pelayanan perpustakaan, karena yang dilihat disini ialah tentang palayanan bagaimana sikap untuk melayani pengunjung (mahasiswa). Oleh karena itu setiap petugas pustakawan hendaknya memiliki wawasan yang luas dan aktif untuk meningkatkan pelayanan, karena dengan pelayanan yang baik dari petugas pustakawan mahasiswa akan tertarik dan puas untuk berkunjung diperpustakaan.

Dari uraian latar belakang di atas, maka penulis tertarik dan akan melaksanakan penelitian tentang Pengaruh Fasilitas Perpustakaan, Kinerja Pustakawan dan Kualitas Informasi Terhadap Kepuasaan Mahasiswa Dalam Menggunakan Perpustakaan Politeknik Negeri Batam.

\section{KAJIAN PUSTAKA perpustakaan}

Perpustakaan menurut Sutarno (2006) adalah "Suatu ruangan, bagian dari gedung atau bangunan, atau gedung itu sendiri, yang berisi buku-buku koleksi, yang disusun dan diatur sedemikian rupa sehingga mudah dicari dan dipergunakan apabila sewaktu-waktu diperlukan oleh pembaca. (Sutarno, NS. 2006. ).

\section{Definisi kinerja}

Wirawan kinerja merupakan singkatan dari kinetika energy kerja yang padanannya dalam bahasa Inggris adalah performance. Kinerja adalah keluaran yang dihasilkan oleh fungsifungsi atau indikator-indikator suatu pekerjaan atau suatu profesi dalam waktu tertentu. 
Adhitomo \& Risfandi, pengaruh fasilitas perpustakaan, kinerja pustakawan dan kualitas informasi ....

Moeheriono kinerja atau performance merupakan gambaran mengenai tingkat pencapaian pelaksanaan suatu program kegiatan atau kebijakan dalam mewujudkan sasaran, tujuan, visi, dan misi organisasi yang dituangkan melalui perencanaan strategis suatu organisasi. Amstrong dan Baron kinerja merupakan hasil pekerjaan yang mempunyai hubungan kuat dengan tujuan strategi organisasi, kepuasan konsumen dan memberikan kontribusi ekonomi.

\section{Definisi informasi}

Foskett mendefinisikan informasi sebagai berikut " Information is knowledge shared by having been communicated ". Ditekankan bahwa informasi menjadi pengetahuan milik bersama ketika informasi tersebut telah dikomunikasikan. Informasi tersebut dapat berupa rekaman ataupun tidak terekam. ( Foskett. A. C. (1996). The Subject Approach of Information (5th ed). London: Clive Bingley ).

\section{Definisi kepuasan pelanggan}

Menurut Sugito (2005), kepuasan pelanggan (mahasiswa ) adalah suatu keadaan terpenuhinya keinginan, harapan, dan kebutuhan pelanggan. (Sugito, H. 2005.).

\section{Hipotesis Penelitian}

Adapun model hipotesis yang digunakan seperti pada gambar dibawah ini:

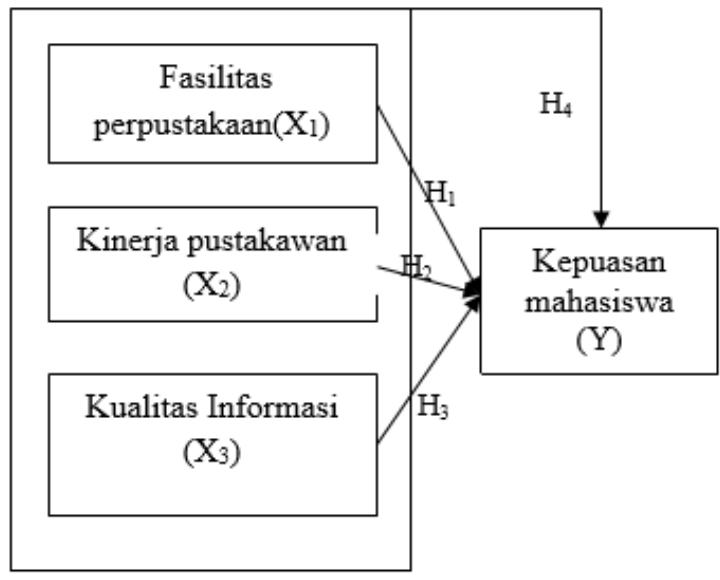

Gambar 1. Model Hipotesis

(Sumber: Pengolahan Data, 2017)

Ingin mengetahui hubungan kualitas terhadap kepuasaan mahasiswa.

Hipotesis alternatif yang dapat dibuat adalah:

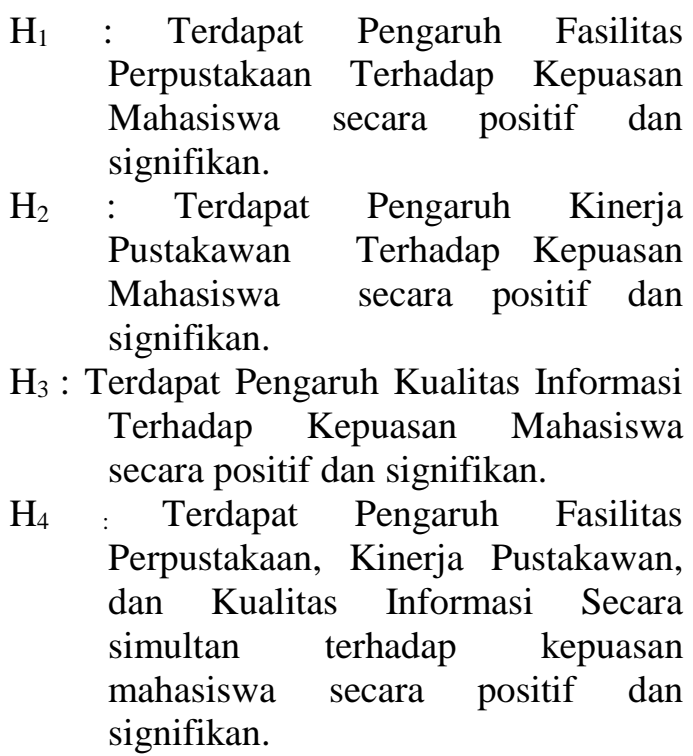

\section{METODE}

Metode yang digunakan dalam penelitian ini yakni explanatory survey. Metode explanatory survey digunakan untuk memprediksi dan menjelaskan hubungan atau pengaruh dari suatu variabel ke variabel lainnya. Metode ini mengemukakan faktafakta yang didukung oleh penyebaran kuisioner kepada responden serta pemahaman literatur. Penelitian ini dilakukan dalam kurun waktu kurang dari 3 bulan, sehingga metode yang digunakan adalah cross sectional method.

Objek yang penulis teliti nantinya adalah para mahasiswa snik Negeri Batam. Sedangkan untul ig lingkup fasilitas perpustakaan. Penulis hanya terfokus untuk meneliti mengenai Fasilitas Perpustakaan, Kinerja Pustakawan Dan Kualitas Informasi di Politeknik Negeri Batam apakah sudah efektif atau tidak.

Sampel dalam penelitian ini sebanyak 100 orang responden, dengan teknik sampling menggunakan purposive sampling. Data yang diambil dalam penelitian berasal dari data primer, yaitu data yang diperoleh langsung dari responden melalui kuesioner dan dokumentasi yaitu data-data yang diperoleh dari setiap bagian yang berkaitan dengan penelitian, seperti profil perusahaan, struktur organisasi, dan lain-lain yang mendukung penelitian ini.

\section{Validitas dan Reliabilitas}

Suatu instrumen dikatakan valid apabila mampu mengukur apa yang diingikan serta dapat mengungkapkan data yang terkumpul 
tidak menyimpang dari gambaran variabel yang dimaksud. Untuk mengetahui apakah kuesioner yang digunakan valid atau tidak, maka $r$ yang diperoleh (rhitung) dikonsultasikan dengan $\left(\mathrm{r}_{\text {tabel }}\right)$ maka instrumen dikatakan valid, dan apabila $\mathrm{r}_{\text {hitung }}>\mathrm{r}_{\text {tabel }}$ maka instrumen dikatakan valid, dan apabila $r_{\text {hitung }}<r_{\text {tabel }}$ maka instrument dikatakan tidak valid. Untuk nilai $r_{\text {tabel }}$ pada penelitian ini sebesar 0.165 . tingkat signifikansi uji reliabilitas adalah 0.6 sehingga suatu instrument dikatakan reliable bila hasil nilai lebih atau sama dengan nilai kritis yaitu sebesar 0.6. hasil uji reliabilitas yang dilakukan menunjukkan bahwa semua variabel yang digunakan untuk penelitian sudah reliabel.

\section{Analisis Data}

Data yang diperoleh dianalisis dengan menggunakan analisis deskriptif dan analisis inferensial. Analisis deskriptif digunakan untuk mengetahui gambaran responden yang menjadi subjek penelitian. Langkah pertama dalam analisis inferensial yaitu Uji Asumsi Klasik yang terdiri dari uji normalitas, uji multikolinieritas, dan uji heteroskedastisitas. Selanjutnya digunakan analisis regresi linier berganda digunakan untuk mengetahui besarnya pengaruh langsung dan tidak langsung antar variabel yang digunakan dalam penelitian ini. Serta melakukan pengujian hipotesis dengan Uji $\mathrm{t}$ (Parsial) digunakan untuk mengetahui pengaruh dari masing-masing variabel, baik variabel bebas terhadap variabel terikat tersebut yang signifikan secara statistik. Menggunakan uji masing-masing koefisien regresi variabel bebas apakah mempunyai pengaruh yang bermakna atau tidak terhadap variabel terikat.

\section{HASIL PEMBAHASAN}

Berdasarkan hasil penelitian diatas disimpulkan bahwa dari total jumlah responden sebanyak 100 orang, responden didominasi dengan jurusan manajemen bisnis sebanyak 45 orang terbukti dengan tingkat persentase responden sebanyak 45\%. Dan responden multimedia dan jaringan sebanyak 28 orang atau dengan presentasi sebanyak $27 \%$. Responden teknik elektro sebanyak 21 orang atau dengan presentase $21 \%$. Dan responden teknik mesin sebanyak 6 orang atau $6 \%$.

\section{Uji Asumsi Klasik}

\section{Uji Normalitas}

Uji statistik sederhana yang sering digunakan untuk menguji asumsi normalitas adalah dengan menggunakan uji normalitas dari Kolmogorov Smirnov. Metode pengujian normal tidaknya distribusi data dilakukan dengan melihat nilai signifikansi variabel, jika signifikan lebih besar dari alpha $10 \%$ (0.1), maka menunjukkan distribusi data normal.

Tabel 1. Uji Normalitas

\begin{tabular}{ll}
\hline & $\begin{array}{l}\text { Unstandardized } \\
\text { Residual }\end{array}$ \\
\hline Asymp. Sig. (2-tailed) & 0.200
\end{tabular}

Sumber: Data diolah, 2017

Tabel diatas menunjukkan bahwa nilai signifikansi variabel yaitu sebesar 0.200 lebih besar dari alpha 0.1 , ini menunjukkan bahwa distribusi data dinyatakan normal.

\section{Uji Multikolinieritas}

Pengujian ada tidaknya gejala
multikolinieritas $\quad \begin{array}{r}\text { dilakukan } \\ \text { dengan }\end{array}$ memperhatikan nilai matriks kolerasi yang dihasilkan pada saat pengolahan data serta nilai VIF (Variance Inflation Factor) dan tolerancenya.

Tabel 2. Uji Multikolinieritas

\begin{tabular}{|c|c|c|c|}
\hline \multirow[t]{2}{*}{ Model } & \multicolumn{2}{|c|}{$\begin{array}{c}\text { Colinearity } \\
\text { Statistics } \\
\end{array}$} & \multirow[t]{2}{*}{ Keterangan } \\
\hline & $\begin{array}{l}\text { Toleran } \\
\text { ce }\end{array}$ & VIF & \\
\hline $\begin{array}{l}\text { Fasilitas } \\
\text { perpustaka } \\
\text { an }\left(\mathbf{X}_{1}\right)\end{array}$ & 0.918 & $\begin{array}{c}1.08 \\
9\end{array}$ & $\begin{array}{l}\text { Tidak } \\
\text { Multikolinier } \\
\text { tas }\end{array}$ \\
\hline $\begin{array}{l}\text { Kinerja } \\
\text { pustakawa } \\
\text { n }\left(\mathbf{X}_{2}\right)\end{array}$ & 0.981 & $\begin{array}{c}1.02 \\
0\end{array}$ & $\begin{array}{l}\text { Tidak } \\
\text { Multikolinieri } \\
\text { tas }\end{array}$ \\
\hline $\begin{array}{l}\text { Kualitas } \\
\text { informasi } \\
\left(\mathbf{X}_{3}\right)\end{array}$ & 0.920 & $\begin{array}{c}1.08 \\
7\end{array}$ & $\begin{array}{l}\text { Tidak } \\
\text { Multikolinieri } \\
\text { tas }\end{array}$ \\
\hline
\end{tabular}

Sumber: Data diolah, 2017

Berdasarkan diatas dapat dilihat bahwa setiap variabel mempunyai nilai tolerance $>0.10$ dan nilai $\mathrm{VIF}<10$, sehingga dapat disimpulkan bahwa tidak terjadi multikolinieritas antara variabel bebas dalam model regresi ini. 
Adhitomo \& Risfandi, pengaruh fasilitas perpustakaan, kinerja pustakawan dan kualitas informasi ....

\section{Uji Heteroskedastisitas}

Salah satu cara untuk melihat ada tidaknya heteroskedastisitas adalah menggunakan uji Glejser. Uji ini dilakukan dengan cara melakukan regersi variabel bebas dengan nilai absolut dari residualnya.

\section{Tabel 3. Uji Heteroskedastisitas}

\begin{tabular}{clc}
\hline No & \multicolumn{1}{c}{ Variabel } & Sig. \\
\hline $\mathbf{1}$ & $\begin{array}{l}\text { Fasilitas } \\
\text { perpustakaan }\left(\mathrm{X}_{1}\right)\end{array}$ & 0.879 \\
\hline $\mathbf{2}$ & $\begin{array}{l}\text { Kinerja } \\
\text { pustakawan }\left(\mathrm{X}_{2}\right)\end{array}$ & 0.208 \\
\hline $\mathbf{3}$ & $\begin{array}{l}\text { Kualitas informasi } \\
\left(\mathrm{X}_{3}\right)\end{array}$ & 0.145 \\
&
\end{tabular}

Sumber: Data diolah, 2017

Berdasarkan Tabel 4.14 di atas dapat dilihat bahwa hasil uji dengan metode Glesjer diperoleh nilai signifikan lebih besar dari 0.1, sehingga dapat disimpulkan data tidak terjadi masalah heteroskedastisitas.

\section{Analisis Regresi Linier Berganda}

Analisis regresi linier berganda digunakan untuk mengetahui kekuatan hubungan dari variabel independen terhadap variabel dependen yaitu fasilitas perpustakaan, kinerja pustakaan, dan kualitas informasi terhadap kepuasan pengguna.

Hasil pengolahan data dengan menggunakan program SPSS selengkapnya akan dijelaskan pada Tabel berikut ini:

\section{Tabel 4. Hasil Analisis Regresi Linier Berganda}

\begin{tabular}{cllll}
\hline $\begin{array}{c}\text { Variabel } \\
\text { Depende } \\
\text { n }\end{array}$ & $\begin{array}{c}\text { Variabel } \\
\text { Indenpende } \\
\mathbf{n}\end{array}$ & B & T & Sig. \\
& & & & \\
\hline & (Constant) & $\begin{array}{l}1.09 \\
6\end{array}$ & 0.24 & 0.80 \\
& & 6 & 6
\end{tabular}

\begin{tabular}{|c|c|c|c|c|}
\hline \multirow{3}{*}{$\begin{array}{l}\text { Kepuasa } \\
\text { n } \\
\text { penggun } \\
\text { a } \\
(Y)\end{array}$} & $\begin{array}{l}\text { Fasilitas } \\
\text { perpustakaa } \\
\mathrm{n}\left(\mathrm{X}_{1}\right)\end{array}$ & $\begin{array}{l}0.25 \\
2\end{array}$ & $\begin{array}{l}1.74 \\
5\end{array}$ & $\begin{array}{l}0.08 \\
4\end{array}$ \\
\hline & $\begin{array}{l}\text { Kinerja } \\
\text { pustakawan } \\
\left(\mathrm{X}_{2}\right)\end{array}$ & $\begin{array}{l}0.60 \\
4\end{array}$ & 2661 & $\begin{array}{l}0.00 \\
9\end{array}$ \\
\hline & $\begin{array}{l}\text { Kualitas } \\
\text { informasi }\left(\mathrm{X}_{3}\right. \\
\text { ) }\end{array}$ & $\begin{array}{l}0.29 \\
8\end{array}$ & & $\begin{array}{l}0.02 \\
8\end{array}$ \\
\hline
\end{tabular}

(Sumber : Pengolahan Data, 2017)

Koefisien regresi dari variabel Fasilitas perpustakaan, Kinerja pustakawan, dan Kualitas informasi memiliki arah positif dan signifikan dalam pengaruhnya terhadap Citra Politeknik Negeri Batam. Sedangkan variabel Kegiatan Sosial memiliki arah positif namun tidak berpengaruh signifikan terhadap Citra Politeknik Negeri Batam. Adapun bentuk model persamaan regresi yang dapat dituliskan dari tabel tables dalam persamaan sebagai berikut:

$\mathrm{Y}=1,096+0,252 \mathrm{X}_{1}+0,604 \mathrm{X}_{2}+0,298 \mathrm{X}_{3}$

\section{Gambar 1. Model Persamaan Regresi Linier Berganda}

pada persamaan regresi linier berganda ini sebesar 1,096 artinya jika fasilitas perpustakaan (X1), kinerja pustakawan (X2), kualitas informasi (X3), maka kepuasan penguna perpustakaan nilainya tetap yaitu sebesar 1.096.

a. Koefisien regresi variabel fasilitas perpustakaan mempunyai arah positif dalam pengaruhnya terhadap kepuasan pengguna perpustakaan yaitu sebesar 0.252

b. Koefisien regresi variabel media kinerja pustakawan mempunyai arah positif dalam pengaruhnya terhadap kepuasan pengguan perpustakaan yaitu sebesar 0.604

c. Koefisien regresi variabel kuaitas informasi mempunyai arah positif dalam pengaruhnya terhadap kepuasan pengguan perpustakaan yaitu sebesar 0.298. 


\section{Pengujian Hipotesis}

Uji t (Parsial)

Uji statistik t dilakukan untuk mengetahui pengaruh masing-masing variabel terhadap variabel dependen secara parsial. Pengujian $t$ yang dilakukan menggunakan nilai $\alpha$ (alpha) sebesar $10 \%$. Dengan demikian perhitungan uji $\mathrm{t}$ dapat dilihat melalui $t_{\text {tabel }}$ yang memiliki alpha $10 \%$ atau 0.1 dan nilai derajat kebebasan (df) yang akan digunakan. Pengujian $t$ ini memiliki ketentuan sebagai berikut:

a. Jika $t_{\text {hitung }}>\mathrm{t}_{\text {tabel }}$ dan nilai signifikansi $<0.1$ maka Ho ditolak dan Ha diterima, jadi variabel independen $(\mathrm{X})$ berpengaruh signifikan terhadap variabel dependen Jika $t_{\text {hitung }}<\mathrm{t}_{\text {tabel }}$ dan nilai signifikansi > 0.1 maka Ho diterima dan $\mathrm{Ha}$ ditolak, jadi variabel indenpenden (X) tidak berpengaruh signifikan terhadap variabel dependen $(\mathrm{Y})$.

Penelitian ini menggunakan signifikansi 0.1 dengan derajat kebebasan $(\mathrm{df})=\mathrm{n}-2$ dengan perhitungan bahwa jumlah responden (n) sebesar 100 maka nilai $\mathrm{df}=100$ - 2 yaitu 98. Maka dapat dilihat pada tabel statistik pada nilai signifikansi 0.1 dengan nilai $\mathrm{df}$ sebesar 98 diperoleh $t_{\text {tabel }}$ sebesar 1.29025.

\section{Tabel 5. Hasil uji t}

\begin{tabular}{|c|c|c|c|}
\hline $\begin{array}{l}\text { Variabel } \\
\text { Dependen }\end{array}$ & $\begin{array}{c}\text { Variabel } \\
\text { Indenpenden }\end{array}$ & $\mathbf{T}$ & Sig. \\
\hline \multirow{4}{*}{$\begin{array}{l}\text { Kepuasan } \\
\text { (Y) }\end{array}$} & (Constant) & 0.246 & 0.806 \\
\hline & $\begin{array}{l}\text { Faslitas } \\
\text { perpustakaan } \\
\left(\mathrm{X}_{1}\right)\end{array}$ & 1.745 & 0.084 \\
\hline & $\begin{array}{l}\text { Kinerja } \\
\text { pustakawan } \\
\left(\mathrm{X}_{2}\right)\end{array}$ & 2.661 & 0.009 \\
\hline & $\begin{array}{l}\text { Kualitas } \\
\text { informasi } \\
\left(\mathrm{X}_{3}\right)\end{array}$ & 2.224 & 0.028 \\
\hline
\end{tabular}

Sumber: Data diolah, 2017

\section{a. Hipotesis 1}

Berdasarkan hasil uji t untuk variabel fasilitas perpustakaan $\left(\mathrm{X}_{1}\right)$ diperoleh t hitung sebesar 1.745 dengan probabilitas sebesar 0.084. Nilai signifikansi tersebut lebih kecil dari 0.1. Sehingga dapat disimpulkan bahwa secara parsial, variabel fasilitas perpustakaan memiliki pengaruh positif dan signifikan terhadap kepuasan pengguna. Hal ini menunjukkan Ha diterima dan Ho ditolak berarti hipotesis 1 diterima.

\section{b. Hipotesis 2}

Berdasarkan hasil uji $t$ untuk variabel kinerja pustakawa $\left(\mathrm{X}_{2}\right)$ diperoleh $\mathrm{t}$ hitung sebesar 2.661 dengan probabilitas sebesar 0.009. Nilai signifikansi tersebut lebih kecil dari 0.1. Sehingga dapat disimpulkan bahwa secara parsial, variabel kinerja pustakawa memiliki pengaruh positif dan signifikan terhadap kepuasan pengguna. Hal ini menunjukkan $\mathrm{Ha}$ diterima dan Ho ditolak berarti hipotesis 2 diterima.

\section{c. Hipotesis 3}

Berdasarkan hasil uji t untuk variabel kualitas informasi $\left(\mathrm{X}_{3}\right)$ diperoleh $\mathrm{t}$ hitung sebesar 2.224 dengan probabilitas sebesar 0.028. Nilai signifikansi tersebut lebih kecil dari 0.1. Sehingga dapat disimpulkan bahwa secara parsial, variabel kualitas informasi memiliki pengaruh positif dan signifikan terhadap kepuasan pengguna. Hal ini menunjukkan $\mathrm{Ha}$ diterima dan Ho ditolak hipotesis 3 diterima.

\section{Pembahasan Penelitian}

Secara umum penelitian ini menunjukkan hasil yang cukup memuaskan. Hasil analisis deskriptif menunjukkan bahwa terdapat 3 hipotesis yang diterima dan 1 hipotesis yang ditolak. Ini menunjukkan bahwa strategi pemasaran dengan menggunakan faslitas perpustakaan, kinerja pustakawan, dan kualitas informasi sudah cukup baik untuk meningkatkan kepuasan pengguna perpustakaan. Penjelasan dari hipotesis tersebut dapat dilihat sebagai berikut:

\section{Pengaruh Fasilitas Perpustakaan $\left(X_{1}\right)$ Terhadap Kepuasan Pengguna}

Berdasarkan hipotesis 1 di atas menunjukkan bahwa $\mathrm{H} 1$ diterima, yang berarti variabel fasilitas perpustakaan memiliki pengaruh yang positif dan signifikan terhadap 
Adhitomo \& Risfandi, pengaruh fasilitas perpustakaan, kinerja pustakawan dan kualitas informasi ....

kepuasaan pengguna. Hasil ini memberi bukti empiris bahwa fasilitas menentukan kepuasan pengguna.

Hasil tersebut sesuai yang diungkapkan oleh Arikunto (1998) yang menyatakan bahwa "Fasilitas adalah segala sesuatu yang dapat memudahkan dan melancarkan pelaksanaan sesuatu". Judul jurnal (Pengaruh Persepsi Mahasiswa Tentang Fasilitas Dan Pelayanan Perpustakaan Terhadap Kepuasan Mahasiswa Pengguna Layanan Perpustakaan Pusat Universitas Negeri Yogyakarta). Hasil penelitian juga sesuai dengan penelitian yang dilakukan oleh Setyawan (2012) dengan hasil yang memuaskan sebesar 6,91 pada fasilitas layanan dengan skala 0,1-10 terhadap kepuasan pengguna perpustakaan di BPADProvinsi Yogyakarta.

\section{Pengaruh kinerja pustakawan $\left(\mathbf{X}_{2}\right)$ terhadap kepuasaan pengguna}

Berdasarkan hipotesis 2 di atas menunjukkan bahwa $\mathrm{H} 2$ diterima, yang berarti variabel kinerja pustakawan memiliki pengaruh yang positif dan signifikan terhadap kepuasan pengguna.

Temuan ini didukung oleh hasil penelitian Widyatmini dan Hakim (2008) yang menemukan adanya pengaruh kompetensi terhadap kinerja. Penelitian ini juga menemukan besarnya kontribusi kompetensi terhadap kinerja adalah $10 \%$. Hasil penelitian lain yang juga menemukan adanya pengaruh kompetensi terhadap kinerja adalah oleh Sanjaya dan Indrawati (2012). Hasil penelitiannya menemukan adanya pengaruh positif kompetensi terhadap kinerja. judul jurnal (Pengaruh Kompetensi Dan Kompensasi Pustakawan Terhadap Kinerja Pustakawan Di Upt Perpustakaan Universitas Malahayati Bandar Lampung).

\section{Pengaruh kualitas informasi terhadap kepuasan pengguna}

Berdasarkan hipotesis $3 \mathrm{di}$ atas menunjukkan bahwa $\mathrm{H} 3$ diterima, yang berarti variabel kualitas informasi memiliki pengaruh yang positif dan signifikan terhadap kepuasan pengguna.

Hasil ini memberi bukti empiris bahwa kualitas informasi menentukan kepuasan pengguna. Judul jurnal ( Pengaruh Kualitas Sistem, Kualitas Informasi Dan Kualitas
Pelayanan Sia Terhadap Kepuasan Mahasiswa) Hasil ini menunjukkan persamaan dengan hasil penelitian terdahulu oleh Negash et al. (2002) yang menunjukkan bahwa kualitas sistem memiliki pengaruh dominan terhadap kepuasan pengguna

4. Pengaruh fasilitas perpustakan (X1), kinerja pustakawan (X2), dan kualitas informasi (X3) terhadap kepuasan pengguna ( mahasiswa)

Berdasarkan uji f di atas menunjukan bahwa yang berarti variabel fasilitas perpustakan (X1), kinerja pustakawan (X2), dan kualitas informasi (X3) secara bersama-sama (simultan) berperngaruh positif dan signifikan terhadap kepuasan pengguna (mahasiswa) hasil ini memberikan bukti empiris bahwa seluluh variabel (X) dapat menentukan kepuasan pengguna perpustakaan (mahasiswa).

Temuan ini mendukung penelitian yang dilakukan oleh DeLone dan McLean (1992) dan Rivard et al. (1997). Judul jurnal (Pengaruh Kualitas Sistem, Kualitas Informasi Dan Kualitas Pelayanan Sia Terhadap Kepuasan Mahasiswa). Menurut DeLone dan McLean (1992) kualitas sistem informasi yang baik, kualitas informasi yang akurat dan relevan, serta kepuasan pemakai setelah menggunakan suatu software akan semakin meningkatkan kebutuhan pemakai dan intensitas penggunaan terhadap penggunaan yang semakin tinggi terhadap software itu berdampak pada semakin tingginya perceived usefulnessatas software yang diimplementasikan. Hal ini akan berdampak pada individu dan perusahaan yang secara tidak langsung berdampak pada perilaku pemakai di dalam organisasi.

\section{PENUTUP}

\section{Kesimpulan}

Faktor fasilitas berpengaruh positif dan signifikan terhadap kepuasan pengguna (mahasiswa). Fasilitas yang dilakukan perpustakaan khususnya di Politeknik Negeri Batam. Dengan demikian hipotesis pertama (H1) yang menyatakan "terdapat pengaruh langsung yang signifikan dari variabel fasilitas perpustakaan terhadap kepuasan pengguna (mahasiswa)" sudah baik dan terbukti dengan nilai deskriptif persentase rata-rata skor fasilitas sebesar 3.035. Dari pernyataan variabel fasilitas perpustakan, responden yang tidak setuju dari 
pernyataan yang ke-6 memiliki persentase sebanyak $43 \%$ dari indikator buku-buku.

Faktor kinerja pustakawan berpengaruh positif dan signifikan terhadap kepusan pengguna. Kinerja pustakawan yang ada saat ini akan meningkatkan kepuasan pengguna. Dengan demikian hipotesis kedua (H2) yang menyatakan "terdapat pengaruh langsung dan signifikan dari variabel kinerja pustakawan terhadap kepuasan pengguna" sudah terbukti masuk dalam baik dengan skor rata-rata 2.88 . Dari pernyataan variabel kinerja pustakawan, responden yang tidak setuju dari pernyataan yang ke-4 memiliki persentase sebanyak $60 \%$ kuantitas kerja.

Terdapat pengaruh positif dan signifikan terhadap mahasiswa tentang kualitas informasi. Hal tersebut ditunjukkan dengan hasil uji demikian hipotesis ketiga (H3) yang menyatakan" terdapat pengaruh langsung". Dari pernyataan variabel kualitas informasi, responden yang tidak setuju dari pernyataan yang ke-3 memiliki persentase sebanyak $22 \%$ dengan indikator akurat

\section{Saran}

Berdasarkan hasil penelitian ini maka ada beberapa saran untuk meningkatkan kepuasan pengguna (mahasiswa). Saran tersebut antara lain:

Untuk fasilitas perpustakaan, sebaiknya dari pengelolaan perpustaakaan ditata kembali, agar ruangan dapat menampung semua yang ingin mengunjungi perpustakaan, maka saran saya perpustakaan mestinya harus diperluas lage. Solusi yang lain ialah dengan menempatkan perpustakaan pada ruangan khusus agar tidak ada gangguan mengenai luas perpustakaan bagi yang ingin mengujungi.

Bagi pustakawan, untuk kepuasan pengunjung yang berdampak pada pengguna, pustakawan baiknya meningkatkan perhatian kepada pengunjung ketika pengguna terdapat masalah, misalnya kesulitan dalam mencari refrensi, pustakawan sebaiknya membantu.

Dengan adanya penelitian ini semoga dapat dijadikan rujukan bagi kampus Politeknik Negeri Batam untuk meningkatkan kesadaran akan perlunya menjaga dan meningkatkan kepuasan bagi pengguna yang bersifat positif yang dilihat oleh masyarakat, kompetitor dan tentunya calon mahasiswa, agar hubungan antara kampus dan lingkungan bisa terjaga lebih baik.

Tidak bisa dipungkiri bahwa persaingan diantara dunia pendidikan khususnya perguruan tinggi sangatlah ketat. Banyaknya perguruan tinggi negeri maupun swasta yang telah menjamur dan berkembang membuat Polibatam harus bisa meningkatkan minat calon mahasiswa untuk menjadikan Polibatam sebagai tempat studinya.

Penulis dalam penelitian ini belum secara mendalam menganalisa variabel maupun indikator-indikator lain yang mempengaruhi kepuasan pengguna perputakaan Politeknik Negeri Batam, sehingga masih memerlukan penelitian lebih lanjut di masa yang akan datang.

\section{Keterbatasan}

Dalam penelitian ini masih banyak kekurangan dan kelemahan, hal ini disebabkan karena keterbatasan peneliti, yaitu Pengambilan data ini menggunakan kuesioner, akan lebih baik lagi jika disertai dengan pengambilan data menggunakan wawancara. Saat pengambilan data peneliti yaitu saat penyebaran kuesioner kepada responden, tidak di pantau secara langsug, yang diberikan oleh responden apakah sesuai dengan pendapat sendiri atau tidak.

\section{DAFTAR PUSTAKA}

Abdullah, M. Ma'ruf, (2014). Manajemen dan Evaluasi Kinerja Karyawan. Perpustakaan Nasional RI: Katalog Dalam Terbitan (KDT). ISBN 10: 60218652-3-5.

Arikunto, Suharsimi. 2006. Prosedur Penelitian Suatu Pendekatan Praktik. Jakarta: Rineka Cipta.

Dyah, Erni susilowati, (2009). Pengaruh Kinerja Pustakawan Terhadap Kepuasan Penggguna Pada Badan Perpustakaan Dan Arsip Daerah Provinsi Daerah Istimewa Yokyakarta.

Dervin, B. (1992). From the mind's eye of the user: The sense-making qualitativequantitative methodology. In J. Glazier \& 
Adhitomo \& Risfandi, pengaruh fasilitas perpustakaan, kinerja pustakawan dan kualitas informasi ....

R. Powell (Eds.), Qualitative research in information management ).

Ghozali, Imam. 2006. Aplikasi Analisis Multivariate dengan Program SPSS.

Ghozali, Imam. 2011. Aplikasi Analisis

Multivariate dengan Program IBM

SPSS19, Edisi 5. Semarang: Badan Penerbit Universitas Diponegoro

Husein, Umar. (2011). Desain Penelitian MDSM Dan Perlikaku Karyawan. Jakarta: Rajawaali Pers.

Irianto, Rudi dan Marimin. (2015). Pengaruh Fasilitas Perpustakaan Dan Kinerja Pustakawan Terhadap Minat Baca Siswa Smk Negeri 9 Semarang. 2252-6544.

Lupiyaodi, Rambat A. Hamdani. (2011). Manajemen pemasaran jasa, edisi kedua ISBN : 979-691-365-8.

Prastia, Ekasari Dan Palupiningdyah. (2016). Pengaruh Peranan Guru, Fasilitas Perpustakaan, Dan pelayanan Pustakawan Terhadap Minat Membaca Diperpustakaan. 2252-6544.

Peraturan Pemerintah No 24 Tahun 2014 Tentang Pelaksanaan UU No 43 Tahun 2007 Tentang Perpustakaan.

Sugiyono. (2016). Metode Pelitian Manajemen . Bandung: Alfabeta

Sugiyono. 2008. Metode Penelitian Bisnis. Cetakan ke-11. Bandung: Alfabeta

Sugiyono. (2014). Metode Pelitian kuantitif kualitatif dan $R \& D$. Bandung : Alfabeta

Sugiyono. 2015. Metode Penelitian Manajemen. Cetakan ke-4. Bandung: Alfabeta

Sugito, H. 2005. Mengukur kepuasan pelanggan. ( on-line ). 12 februari 2017.

Surmawan,Ujang, Dkk. (2012) Riset Pemasaran Dan Konsumen ISBN 978-979-439-4104.

Sunyoto, Danang. (2015). Perilaku Konsumen dan Pemasaran . Jakarta : PT. Buku Seru.
Sutabri,Tata. (2005). Sistem Informasi Manajemen. Yogyakarta : Andi Offset).online 18-april-2017.

Widjaja, H. A.W. (1997). Komunikasi : Komunikasi dan Hubungan Masyarakat. Jakarta: Bumi Aksara

Umar, Husen . (2009). Metode Penelitian Untuk Skripsi Dan Tesis Bisnis . ( Edisi Kedua ). Jakarta: Rajawali Pers.

Zahara, Zurni Samosir, (2005) Pengaruh kualitas pelayanan terhadap kepuasan mahasiswa menggunakan perrpustakaa 